\title{
THE IMPACT OF PARENTS' EDUCATION AND ATTENDING VOCATIONAL HIGH SCHOOL TO COLLEGE ENTRANCE
}

\author{
Wahyudi Wicaksono \\ Universitas Indonesia \& ISS-Erasmus Den Haag Netherlands \\ wahyudi.wicaksono@gmail.com \\ Robert A. Sparrow \\ ISS-Erasmus Den Haag Netherlands \& Wageningen University Netherlands \\ sparrow@iss.nl \\ Peter van Bergeijk \\ ISS-Erasmus Den Haag Netherlands \\ vanBergeijk@iss.nl
}

\begin{abstract}
Using IFLS data 2007 and 2014, this study aims to examine the impact of parents' education and attending vocational high school to the probability of children attending tertiary education. This study is motivated by the government plan in increasing the proportion of vocational high school graduates compare to general high school graduates. Multinomial-Logit model is used to examine the senior high school types, Logit and Probit are used to examine the decision on pursuing tertiary education. The main conclusions are (1) parents' education has significant impact on the children's senior high school preference and college enrollment, (2) children who attended vocational senior high school have a lower probability to enrol in tertiary education compared to those who attended general senior high school or MA
\end{abstract}

Keywords: social mobility, vocational high school, college entrance 


\section{INTRODUCTION}

The discussion about general versus vocational secondary education recently is become a popular research topic in the educational study. This subject is soaring along with the emerging of vocational expansion policies, especially in developing countries including Indonesia.

The modern debate is about the comparison return on education between general and vocational secondary education. Return in labor market and income is researched by Bennell (1996), Mane (1998), Chen (2009), Newhouse \& Suryadarma (2011), Sohn (2013), Mahirda \& Wahyuni (2016), Hanushek, et al. (2017). Few who study the comparison in academic performance and college entry, Chen (2009) compares Indonesia vocational and general graduates in college entrance, and Loyalka et al. (2015) compare working skill and academic performance of general and vocational students of China senior secondary. Another unpopular study is the determinant of selecting general over vocational secondary education and vice versa as we know, in Indonesia only researched by Chen (2009) and Newhouse \& Suryadarma (2011) using Indonesia data.

The study about the comparison between academic and vocational is relevance in Indonesia. Since Government of Indonesia plans to expand vocational education in secondary and tertiary level. The Ministry of Education formalized vocational education expansion planning in its Strategic Planning document year 2005-2009. (Ministry of National Education, 2006). This plan was established in President Susilo Bambang Yudhoyono administration era and continued in Joko Widodo era.

Moreover the government also sets an ambitious target in the vocational education expansion. The government targets in 2015 the proportion of vocational high school student to general high school student is 70 by 30 percent. As information, in 2004 only 30 percent of students who enrolled in the vocational senior high school and the rest, 70 percent enrolled in general senior high school. Government plans to increase the number of vocational school or convert the general high school into vocational high school. (Ministry of National Education, 2006).
The government planning needs to deal with the parents' preferences. The parents' preferences will determine the children senior high school choice between vocational or general high school. Since people is a rational creature. Breen \& Goldthorpe (1997) try to explain the difference in educational choice among people using rational action theory. According to their theory, people will rationally act when they are deciding an educational track. Individuals in this case parent and children are assumed to know about the cost, benefit, and consequences for every choice. Modify an option later is costly. Therefore, in choosing two alternatives, they need to compare the cost and benefit of every decision, assessing the success possible, and measure the available source to finance the choice.

Green \& Goldthorpe (1997) explain that the family's social class also affects children educational decision. Effect of family's social class raises class differential in the educational decision. The class differential can be derived from three primary mechanisms: relative risk aversion, differences in ability and expectations of success, and differences in the resources. Chernichovsky and Meesok said that "the relatively wealthy and welleducated (parents) shun vocational training..." (Chernichovsky \& Meesok, 1985: iii), sending their children to a tertiary education is the reason why wealthy parent avoid vocational training because they presume attending vocational education will reduce the probability to be accepted in higher education. Foster (1965) in (Ziderman, 1997) stated the reason why parents in Ghana avoided to send their children to vocational high school. According to Foster, the reason is the expectation of benefit from academic secondary schools. "Academic education was seen as pre-eminently vocational in providing access to stable, well-paid clerical and administrative jobs within the growing public sector; at the same time the demand for technical skills was growing slowly." (Ziderman 1997, p. 356).

Some studies find that attending vocational high school is detrimenal to the children's education advancement. Chen's (2009) finding, using data from Indonesia Family Life Survey 2000 she found students who attended vocational senior secondary school in Indonesia get a lower final exam score compared to the general senior secondary stu- 
dents. Because the academic skill is essential for pursuing tertiary education, Chen concluded that attending vocational high school decrease the students probability to continue to higher education. This finding is supported by Loyalka et al. (2015). Using China data, Loyalka et al. (2015) find that attending in computing vocational education does not improve student computing ability, moreover attending vocational education reduce their academic skill especially math.

According to Corak $(2004$, p. 3) "the relationship between the socio-economic status of parents and the status and income their children will attain in adulthood." is the indication of generational mobility. Stronger the relationship between parent social status and children social status is an indication of low generational mobility. Low generational mobility has implication to the intergenerational inequality. Children whom born from low socio-economic status family will get low socio-economic status when they are adult and vice versa. From our finding, we can conclude that there is low generational mobility in term of education. Because children whom born in the high education parent tend to get high education as well and vice versa.

This paper tries to determine the existence of social mobility and intergenerational inequality by examining people educational choice. The intergenerational inequality only happens when the parents's education have significant impact in the children's high school choice and in children college entrance. This paper also examine the impact of attending vocational high school to the college entrance.

This study is important in determining whether the government plan in expanding vocational education will lead to the inequality or not. When attending vocational high school significantly reduce the probability of children attending tertiary education, it means that expanding vocational high school will lead reducing tertiary education enrolment rate in the future.

This study is motivated by the vocational education expansion planning in senior secondary and tertiary education. Another motivation for this study is a prediction of demographic bonus that will happen in 20202030. This study will examine the individual respond to the vocational expansion plan and measure the ability of vocational secondary as a milestone in higher education. The focus is comparing between general and vocational senior high school. This research tries to answer the research questions below.

Do parents' education significantly affect senior high school tracks decision and tertiary education entry?

Do schools availability affect students' choice of senior high school types? (we use school availability as a proxy of vocational secondary school expansion)

Do vocational graduates have a lower probability to continue to college?

To investigate those research questions, we will use data from Indonesia Family Life Survey (IFLS) 2007 and 2014 with following the track of junior high school graduates who graduated in 2002 to 2010. In this study, we will use three primary variables, individual characteristics variables, family characteristics variables and educational facility availability variables. We will use category school types as Newhouse \& Suryadarma by dividing senior high school type into general public school, general private school, vocational public school and vocational private, and we add Madrasah Aliyah (MA/religious senior high school). Different from Newhouse \& Suryadarma, in this research paper, we will use final exam score as the variable of individual ability instead of the grade repetitions. And also we use school availability as a variable of interest and a control variable to avoid heterogeneity.

\section{RESEARCH METHODOLOGY}

In this research, I will propose two main models, the first model is related to the people choice after graduating from junior high school and the second model is related to the people choice after graduating from senior high school.

The first model is multinomial logit. This model is developed from the combination model which are used by Newhouse \& Suryadarma (2011) and Chen (2009). Newhouse \& Suryadarma use multinomial logit to examine the senior secondary school choice. Newhouse \& Suryadarma include non-senior secondary, general public, vocational public, private general and private vocational as school choice, while Chen only 
752 (31.29 percent) attended Vocational SHS, 227 (9.45) attended MA, and 445 (18.52) not enrolled in senior high school (JHS). Newhouse \& Suryadarma (2011) excluded students who attended senior high school with Islamic curriculum because of the small share, in this paper we still include them even though only 10 percent student who attend the Islamic senior high schools.

\section{RESULT AND ANALYSIS}

In this session, we will discuss the regression result of children's educational decision after graduating from junior high school. The children can choose to continue their education to senior high school or enough with junior high school. For those who continue to senior high school, they also need to decide in what type of school they will enrol. The type of schools can be divided into: general senior high school, vocational senior high school, and for Muslim children, they also can choose Madrasah Aliyah (MA/ religious school), thus we have four choices.

The table 1 shows determinant of student attending different senior high school types. the result of multinomial logit model with dependent variables are senior high school types and without considering the difference between public and private senior secondary school institutions. The independent variables are categorized into three characteristics; individual characteristics, family characteristics, and residential characteristics. To get robust estimation, the regression is clustered base on the provincial level to avoid heteroscedasticity effect.

From the regression, we found that junior high school exam score and age when graduated from junior high school have a significant effect on the probability selecting general high school or does not enrol in senior high school. Increase one point junior high school score from the mean will increase the probability attending general high school by 2.66 percent and decrease the likelihood to not enrol in senior high school by 1.72 percent. Increasing one year of children age will decrease the probability enrol to general senior high school by 3.33 percent but increase the probability of drop out by 3.76 percent. Gender is still used as consideration when children choose between general high school and vocational high school, a female child has significant lower probability to attend vocational high school than a male child by 7.45 percent, and female children have higher probability to not enrol in senior high school by 4.68 percent. All individual characteristics variables have influence in consideration for children in deciding to enrol or not enrol in senior high schools.

Parent education have positive and significant effect in the probability selecting general senior high school and have negative and significant effect in the probability to not enrol in senior high school. The probability a child enrol in general high school is increasing by 0.83 percent and the probability a child not enrol in senior high school is decreasing by 1.04 percent when his/her father year of schooling one year higher than the average fathers' year of schooling. The mother education effect in the children decision is bigger than father effect, it can be seen from the marginal effect magnitude.

Household income has positive and significant impact in the children probability in selecting general senior high school, yet has negative and significant impact in the children selecting MA and not attending senior high school. Increasing 1 percent of income from the mean will increase the probability a child enrols in general senior high school by 1.95 percent and decrease the probability a child enrols in MA by 1.16 percent and decrease the probability a child not enrol in senior high school by 3.66 percent.

Rural children have 8.04 percent lower probability to enrol in vocational, have 5.56 percent higher probability to enrol in MA, and have 6.39 percent higher probability to not enrol in senior high school compare to the urban children. The vocational education availability also increases the probability a child to enrol in vocational high school but decrease the probability a child to enrol in MA. The vocational education availability does not significantly affect the probability of a child to enrol in general senior high school. The proportion of private school compare to public school has significant effect in all educational choice, it has significant and negative effect in general senior high school choice, but has positive and significant in other choices. 
Table 1. Determinant of Student Selecting High School Types

\begin{tabular}{|c|c|c|c|c|}
\hline & \multicolumn{4}{|c|}{ Multinomial Logit Marginal Effect } \\
\hline & $\begin{array}{c}\text { General } \\
\text { SHS }\end{array}$ & $\begin{array}{c}\text { Vocational } \\
\text { SHS }\end{array}$ & MA & $\begin{array}{l}\text { No Senior } \\
\text { Secondary }\end{array}$ \\
\hline Personal Characteristics & \multicolumn{4}{|c|}{$(1)$} \\
\hline JHSScore & $\begin{array}{c}2.66 \\
(2.68)^{* *}\end{array}$ & $\begin{array}{l}-0.57 \\
(0.64)\end{array}$ & $\begin{array}{l}-0.37 \\
(0.7)\end{array}$ & $\begin{array}{c}-1.72 \\
(2.72)^{* *}\end{array}$ \\
\hline Age When Graduated JHS & $\begin{array}{c}-3.33 \\
(3.63)^{* *}\end{array}$ & $\begin{array}{c}0.49 \\
(0.45)\end{array}$ & $\begin{array}{l}-0.91 \\
(0.98)\end{array}$ & $\begin{array}{c}3.76 \\
(3.46)^{* *}\end{array}$ \\
\hline Female (dummy) & $\begin{array}{c}2.82 \\
(1.24)\end{array}$ & $\begin{array}{c}-7.45 \\
(4.37)^{* *}\end{array}$ & $\begin{array}{l}-0.05 \\
(0.04)\end{array}$ & $\begin{array}{c}4.68 \\
(2.05)^{*}\end{array}$ \\
\hline \multicolumn{5}{|l|}{ Family Characteristics } \\
\hline Father years of schooling & $\begin{array}{c}0.83 \\
(3.59)^{* *}\end{array}$ & $\begin{array}{c}0.05 \\
(0.29)\end{array}$ & $\begin{array}{c}0.15 \\
(1.05)\end{array}$ & $\begin{array}{c}-1.04 \\
(7.24)^{* *}\end{array}$ \\
\hline Mother years of schooling & $\begin{array}{c}1.95 \\
(5.4)^{* *}\end{array}$ & $\begin{array}{l}-0.29 \\
(1.15)\end{array}$ & $\begin{array}{l}-0.25 \\
(1.54)\end{array}$ & $\begin{array}{c}-1.40 \\
(5.28)^{* *}\end{array}$ \\
\hline Ln Household Income & $\begin{array}{c}3.36 \\
(4.4)^{* *}\end{array}$ & $\begin{array}{c}1.45 \\
(1.32)\end{array}$ & $\begin{array}{l}-1.16 \\
(2.18)^{*}\end{array}$ & $\begin{array}{c}-3.66 \\
(5.03)^{* *}\end{array}$ \\
\hline \multicolumn{5}{|l|}{ Residence Characteristics } \\
\hline Rural (dummy) & $\begin{array}{l}-3.90 \\
(1.33)\end{array}$ & $\begin{array}{c}-8.04 \\
(2.05)^{*}\end{array}$ & $\begin{array}{c}5.56 \\
(3.67)^{* *}\end{array}$ & $\begin{array}{c}6.39 \\
(3.15)^{* *}\end{array}$ \\
\hline Proportion of Vocational High School in district & $\begin{array}{r}-22.50 \\
(1.38)\end{array}$ & $\begin{array}{c}50.01 \\
(2.62)^{* *}\end{array}$ & $\begin{array}{c}-37.91 \\
(-3.58)^{* *}\end{array}$ & $\begin{array}{l}10.41 \\
(0.96)\end{array}$ \\
\hline Proportion of Private High School in district & $\begin{array}{l}-68.48 \\
(5.3)^{* *}\end{array}$ & $\begin{array}{c}38.60 \\
(2.75)^{* * *}\end{array}$ & $\begin{array}{c}11.84 \\
(2.74)^{* *}\end{array}$ & $\begin{array}{c}18.03 \\
(2.38)^{*}\end{array}$ \\
\hline Base Probability & 43.34 & 34.73 & 8.74 & 13.19 \\
\hline Number of Obs & 2403 & & & \\
\hline Pseudo R2 & 0.11 & & & \\
\hline
\end{tabular}

Notes: $* 5 \%$ significance; $* * 1 \%$ significance; the marginal effects are in percent, t-statistics in parentheses, the result is robust from heteroscedasticity, clustered base on province

After graduating the senior high school level, children can directly join the work force by entering labour market or continue their education to the university level. The following regression is used to examines the children decision after graduating from senior secondary schools. In this regression, we use two methods, probit and logit model.

According to the estimation in table 2, we can see that two methods, probit and logit, do not show a different result in term of statistical significance, sign, and pseudo Rsquare. In term of variables significance, we found that seven out of ten variables show significant result. Only MA dummy, rural dummy and constant do not show significance result. Four out of eight coefficient shows statistically significance.
All individual characteristics variables have a significant effect in the college entry decision except Junior high school score. Junior high school score is used to measure the initial student ability. Senior secondary score as proxy of individual's ability has positive and significant effect to the college entry decision. Increase senior high school score by one point increase the probability a child attends tertiary education by 3.33 percent in probit and 3.53 in logit model. While, age shows the opposite sign. It means that older children have lower probability to continue their education to tertiary education. With the same characteristics, female children have higher probability to enrol in tertiary education than their male peers about 6 percent. The statistics show significant at $5 \%$ 
in logit model but do not show significance in probit estimation. Senior secondary types have effect in the college entry decision. General senior high school graduates have significantly higher probability to enrol in university than the vocational senior high school graduates. But there is no significant difference in probability to enrol in tertiary education between MA graduates and general secondary school graduates. From three types of senior secondary education, we can see that vocational secondary graduates have the lowest probability to enrol in tertiary education, and general secondary graduates have the highest probability to enrol in tertiary education. Attending vocational senior high school will decrease the probability a child enrols tertiary education about 28 percent compare to attending general high school.

Family characteristics also have an effect in tertiary enrolment decision. Parent education and family income have a positive and significant effect to the probability a child enrol in tertiary education. Increasing father/mother's year of schooling by one year will increase the probability a child enrols in tertiary education about 1.7 percent. Household income also has positive and significant effect in the decision of children tertiary education enrolment. Increasing the family income by one percent will increase the probability a child enrols in tertiary education by 5 percent. There is no significant different between urban and rural children in tertiary education enrolment.

Table 2. The Likelihood in College Entrance

\begin{tabular}{|c|c|c|}
\hline & Probit: College entry & Logit: College entry \\
\hline Personal Characteristics & $(3)$ & $(4)$ \\
\hline \multirow[t]{2}{*}{ SHS Score } & 3.33 & 3.53 \\
\hline & $(2.99)^{* *}$ & $(2.91)^{* *}$ \\
\hline \multirow[t]{2}{*}{ JHS Score } & 2.02 & 2.01 \\
\hline & $(1.28)$ & $(1.23)$ \\
\hline \multirow[t]{2}{*}{ Age When Graduated JHS } & -4.62 & -4.97 \\
\hline & $(2.41)^{* *}$ & $(2.35)^{*}$ \\
\hline \multirow[t]{2}{*}{ Female (dummy) } & 6.19 & 6.59 \\
\hline & $(1.91)$ & $(1.98)^{*}$ \\
\hline \multicolumn{3}{|l|}{ Senior secondary types } \\
\hline \multirow[t]{2}{*}{ Vocational SHS (dummy) } & -27.60 & -27.80 \\
\hline & $(12.45)^{* *}$ & $(12.46)^{* *}$ \\
\hline \multirow[t]{2}{*}{ MA (Islamic School) (dummy) } & -1.23 & -1.42 \\
\hline & $(0.2)$ & $(0.23)$ \\
\hline \multicolumn{3}{|l|}{$\underline{\text { Parent Characteristics }}$} \\
\hline \multirow[t]{2}{*}{ Father years of schooling } & 1.70 & 1.72 \\
\hline & $(9.6)^{* *}$ & $(9.08)^{* *}$ \\
\hline \multirow[t]{2}{*}{ Mother years of schooling } & 1.68 & 1.69 \\
\hline & $(3.67)^{* *}$ & $(3.69)^{* *}$ \\
\hline \multirow[t]{2}{*}{ Ln Household Income } & 5.18 & 5.32 \\
\hline & $(5.18)^{* *}$ & $(5.49)^{* *}$ \\
\hline \multirow[t]{2}{*}{ Rural } & -1.67 & -1.76 \\
\hline & $(0.53)$ & $(0.53)$ \\
\hline Base probability & 32.27 & 31.18 \\
\hline Observations & 1,564 & 1,564 \\
\hline Pseudo R-Square & 0.194 & 0.196 \\
\hline
\end{tabular}

Notes: * 5\% significance; ** $1 \%$ significance; the marginal effects are in percent, tstatistics in parentheses, the result is robust from heteroscedasticity, clustered base on province 


\section{Analysis}

According to our prediction, parent educational attainment has significant effect in children senior secondary education decision. Our hypothesis is "parent with higher educational attainment will tend to send their children to academic secondary over the vocational high schools." From the regression our, we found that father and mother education have positive and significant effect in the probability of children to enrol in general senior high school. From the marginal effect magnitude, we can see that the parent education shows bigger magnitude in the public and private general senior high schools compare to the magnitude of public and private vocational high schools. It means parent with higher educational attainment will tend to send their children to the general high schools than to send their children to vocational high schools. This finding is in line with Chen (2009) and Newhouse \& Suryadarma (2011) finding. The finding concords with Chernichovsky \& Meesok, (1985) suggestion. According to Chernichovsky \& Meesok well-educated parent tend to avoid sending their children to vocational education.

Another finding is related to the impact of school availability to student educational choice. From the regression, we found that the proportion of vocational school to total senior high school has positive and significant effect to the probability attending vocational education. Higher the proportion of vocational schools in the children district, the probability of the children attending vocational education become higher. This finding is almost similar with Chen (2009) finding, she measures this kind of effect using the share of vocational graduates in the community where the children live. We use the proportion of the number vocational school to the total senior high school to give more insight about the effect of government policy in vocational education expansion to the educational choice. School provision is a real proof of government commitment in the vocational education expansion. The vocational education expansion might have bad effect to the senior secondary enrolment. Higher the proportion of vocational school higher probability the children in the district do not continue to the senior high school. As we discuss in chapter 3, attending the vocational senior high school is relatively more expensive than attending the general senior high school. Cost of attending education can be a reason for children to not enrol in senior high school. This finding is also supported by the effect of proportion of private school to the children enrolment. We found that higher share private education institutions in a district, higher the probability children in that district enrol in senior secondary school. Increase the proportion by hundred percent will decrease senior high school enrolment by 19.18 percent. As we know, that private education institutions are tuition driven, they will charge higher fee than the public education institutions. We suspect that cost of attending senior high school become a barrier for children to attend senior high school.

As we expected, the parent year of schooling has a positive and significant effect to the probability a child enrols in tertiary education. Chen (2009) and Ogawaa \& Iimuraa (2010) have a similar finding with us. They find that head of households' education have a positive and significant effect to the probability of the children pursuing tertiary education. This empirical finding is supported by some theories such as rational action theory by Breen and Goldthorpe (1997) or with subjective expected utilities by Esser (1999) or "intergenerational class maintenance (Becker 2003). In the rational action theory Breen and Goldthorpe also explain about the relative risk aversion. Relative risk aversion explains the relationship between parents' education and their children's education. According relative risk aversion, parents expect their children social-economic status not lower than the parents' social-economic status include the educational attainment.

According to Corak (2004:3) "the relationship between the socio-economic status of parents and the status and income their children will attain in adulthood." is the indication of generational mobility. Stronger the relationship between parent social status and children social status is an indication of low generational mobility. Low generational mobility has implication to the intergenerational inequality. Children whom born from low socio-economic status family will get low socio-economic status when they are adult and vice versa. From our finding, we can conclude that there is low generational mobility in term 
of education. Because children whom born in the high education parent tend to get high education as well and vice versa.

We also examined the effect of attending vocational high school to the probability attending tertiary education. We found children who attend vocational secondary school have a lower probability to enrol to the tertiary education compare to their peers from the others secondary school types. This finding is the same with Chen (2009) finding. According to Chen, attending the vocational high school does not have effect to the probability attending tertiary education when it is controlled with the senior high school final exam score, but it has effect when it is not controlled with the senior high school final exam score. In our paper, we already control the regression with senior high school exam score at beginning, even we add junior high school exam score as the initial score. We found that both variables, senior high school final exam score and attending vocational high school, have a significant effect to the probability of enrolling in tertiary education with an opposite sign. Attending vocational high school gained negative sign, while senior high school exam score gained positive sign.

From the regression about senior high school decision, we found that children from low education parents tend to attend vocational high school than attending general high schools. And we also know that parents with low education have a low probability to send their children tertiary education. From those finding we suggest that the vocational high school is the choice for those who do not have intention in pursuing tertiary education, especially for those who come from low education family.

Our conclusion is in line with Breen and Goldthorpe (1997) assumption. Breen and Goldthorpe assumed that decision of entering an $n$ level of education is affected by the expectation of gaining access to level $\mathrm{n}+1$. Therefore, for those who attending general senior high school expect to get access to tertiary education, and for those who attending vocational senior high school expect to get direct access to the labour market.

\section{CONCLUSION}

This study has three goals, first goal is examining the relationship between parents' education attainment and children educational decision, the first decision related with children decision after graduating junior high school and the second decision is after graduating senior high school. The second goal is examining the role of educational expansion through educational facilities provision to children decision. And the last goal is finding the relationship between children decision in senior secondary education to college entry.

In addressing that three goals, we conduct two regressions. The first regression is multinomial logit model to examines the impact of parental educational attainment and educational provision to senior secondary enrolment decision. The second regression is logit/probit model to examines the impact of parental educational attainment and senior secondary types to college enrolment decision.

From the analysis in chapter 5 , we can conclude that: (1) Parents' education have a positive and significant effect in promoting their children to enrol in general high school, especially in attending general public high school. Well-educated parents tend to avoid sending their children to vocational education. (2) The education availability has a significant effect in influencing children educational decision. The increase in the proportion of vocational high school to general senior high school facilities increase the probability a child to enrol in vocational high school, yet it also increases the probability a child does not enrol in senior high school. The proportion of private school also has the same impact as the proportion of vocational high school. Increasing proportion of private senior high school to public senior high school also increases the probability a child to enrol in private senior high school. Increase in the proportion of private to public senior high school will significantly decrease the probability a child enrols to senior high school. (3) Parents' education also has a positive and significant effect to the probability a child attends tertiary education. (4) Attending vocational senior high school decreases the probability a child attends tertiary education.

From the policy perspective, increasing the share of vocational senior high school could be an effective way to increase the share of vocational senior high school enrolment. But the government needs to consider the side effect of increasing the proportion of vocatio- 
nal senior high school, the first it may increase the probability a child not attending senior high school. It is still debatable because according to Pittman (1991) there is no evidence that attending vocational high school could reduce the drop out rate. The second it will decrease the probability senior high school graduates attending tertiary education. Our finding indicates attending vocational high school can reduce the probability a child to enrol in tertiary education. The government also needs to consider the people taste or preference in educational choice, from the regression we can see that high education parents still prefer academic senior high school for their children than vocational senior high school.

We still witnessed a class differentials in the children educational choices. The more educated parents with senior high school education or college degree education tend to send their children to the more academic senior high schools. Parents with junior high school and elementary education see general and vocational high school indifferently. We also found that higher parents' education is lower the probability their children do not continue to senior high school. For policy perspective, the government needs to give incentives and support to the children from low educated parents to continue their education to the highest level.

\section{REFERENCES}

ASEAN. (2015). ASEAN statistical yearbook 2014. Jakarta: ASEAN Secretariat.

Becker, G. S. (1993). Human capital: a theoretical and empirical analysis with special reference to education (3rd Edition ed.). Chicago: The University of Chicago Press.

Becker, R. (2003). Educational expansion and persistent inequalities of education: utilizing subjective expected utility theory to explain increasing participation rates in upper secondary school in the Federal Republic of Germany. European Sociological Review, 19(1), 1-24.

Becker, R., \& Hecken, A. E. (2009). Higher education or vocational training? an empirical test of the rational action model of educational choices suggested by Breen and Goldthorpe and Esser. Acta Sociologica, 52(1), 25-45.

Bedi, A., \& Garg, A. (2000). The effectiveness of private versus public schools: The case of Indonesia. Journal of Development Economics, 61(2).

Bennell, P. (1996). General versus vocational Secondary education in developing countries: A review oof the rates of return evidence. The Journal of Development Studies, 33(2), 230-247.

Breen, R., \& Goldthorpe, J. H. (1997). Explaining educational differentials toward a formal rational action theory. Rationality and Society, 9(3), 275-305.

Calero, C., Bedi, A., \& Sparrow, R. (2008). Remittances, liquidity constraints and human capital investments in Ecuador. ISS Working Paper, 458.

Cappelari, L. (2004). High school types, academic performance, and early labour market outcomes. IZA DP. 1048. Bonn: Institute for the Study of Labor.

Chen, D. (2009). Vocational schooling, labor market outcomes, and college entry. World Bank Policy Research Working Paper, 4814, 1-25.

Chernichovsky, D., \& Meesok, O. A. (1985). 'School enrolment in Indonesia' staff working paper 746. Washington D.C.: World Bank.

Direktorat Agama dan Pendidikan Bappenas. (2010). Potret pendanaan perguruan tinggi. Jakarta: Bappenas.

Esser, H. (1999). Soziologie: spezielle gundlagen, i. situationslogik un handeln. Frankfurt: Frankfurt am Main.

Gaddah, M., Munro, A., \& Quartey, P. (2016). 'Education subsidy and school enrollments in rural Ghana'. International Journal of Educational Development, 46, 143-152.

Granado, F. J., Fengler, W., Ragatz, A., \& Yavuz, E. (2007). Investing in Indonesia's education: allocation, equity, and eficiency of public expenditures (Vol. 4329). Washington D.C.: The World Bank, Pover Reduction and Economic Management and Human 
Development of the East Asia and Pacific Region.

Hanushek, E. A., Schwerdt, G., Woessmann, L., \& Zhang, L. (2017). General education, vocational education, and labor-market outcomes over the lifecycle. The Journal of Human Resources, 52(1), 48-87.

Hillmert, S., \& Jacob, M. (2003). Social inequality in higher education: is vocational training a pathway leading to or away from university? European Sociological Review, 19(3), 319-334.

Lanjouw, P., Pradhan, M., Saadah, F., Sayed, H., \& Sparrow, R. (2002). Poverty, education and health in Indonesia: who benefits from public spending? In C. Morrisson (Ed.), Education and Health Expenditure, and Development: The Cases of Indonesia and Peru (pp. 1778). Paris: Development Centre Of The Organisation For Economic Cooperation and Development.

Loyalka, P., Huang, X., Zhang, L., Wei, J., Yi, H., Song, Y., . . Chu, J. (2015). The impact of vocational schooling on human capital development in developing countries: Evidence from China. The World Bank Economic Review, 30(1), 143-170.

Mahirda, K., \& Wahyuni, H. (2016). Returning to general and vocational high-schools in Indonesia. Review of Economic and Business Studies, 9(2), 928.

Mane, F. (1998). Trends in the payoff to academic and occupation-specific skills: the short and medium run returns to academic and vocational high school courses for non-college-bound students. Economics of Educational Review, 18, 417-437.

Ministry of Domestic Affair. (2014). www.kemendagri.go.id. Retrieved 08 10, 2017, from http://otda.kemendagri.go.id/CMS/Imag es/SubMenu/totalDOB.pdf

Ministry of Education. (2013). Regulation no 70 year 2013 "Framework and Curriculum for Vocational Senior High
School". Jakarta: Ministry of Education.

Ministry of National Education. (2006).

Rencana strategis departemen

pendidikan nasional tahun 2005-2009

(Ministry of National Education

Strategic Planning year 2005-2009).

Jakarta: Ministry of National Education.

Ministry of National Education. (2015).

Rencana strategis Kementerian

Pendidikan dan Kebudayaan 2015-2019.

Muttaqin, T. (2017). The education divide in Indonesia: Four essays on determinants of unequal access to and quality of education. Groningen: University of Groningen (Ph.D. thesis).

Newhouse, D., \& Suryadarma, D. (2011). The value of vocational education: high school type and labor market outcomes in Indonesia. The World Bank Economic Review, 25(2), 296-322.

OECD/Asian Development Bank. (2015). Education in Indonesia: rising to the challenge. Paris: OECD Publishing.

Oey-Gardiner, M., \& Gardiner, P. (2013). Indonesia's demographic dividen or window of opportunity. Masyarakat Indonesia, 39(2), 481-504.

Ogawaa, K., \& Iimuraa, K. (2010). Determinants of access and equity in tertiary education: The Case of Indonesia. Excellence in Higher Education, 1, 3-22.

Pittman, R. B. (1991). Social factors, enrollment in vocational/technical courses, and high school dropout rates. The Journal of Educational Research, 84(5), 288-295.

Rajkumar, A. S., \& Swaroop, V. (2002). Public spending and outcomes: does governance matter? The World Bank.

Republic Indonesia. (1945). Undang-Undang Dasar 1945/Indonesian Constitution. Jakarta: Indonesia.

Sawitri, D. R., Creed, P. A., \& ZimmerGembeck, M. J. (2014). Parental influences and adolescent career behaviours in collectivist cultural setting. International Journal of Vocational Guidance, 14, 161-180. 
Sohn, K. (2013). Monetary and nonmonetary returns to education in Indonesia. The Developing Economies, 1, 34-59.

Sparrow, R. (2007). Protecting education for the poor in times of crisis: An evaluation of a scholarship program in indonesia. Oxford Bulletion of Economics and Statistics, 69(1), 99-122.

Sulistyaningrum, E. (2016). Impact evaluation of the school operational assistance program (BOS) Using the matching method'. Journal of Indonesian Economy and Business,, 31(1), 33-62.

Suryadarma, D., Suharyadi, A., \& Sumarto, S. (2006). Causes of low secondary school enrollment in Indonesia. Jakarta: SMERU Research Institute.

The World Bank. (2005). Expanding opportunities and building competencies for young people a new agenda for secondary education. Washington DC: The International Bank for Reconstruction and Development.

The World Bank. (2008). Spending for development : making the most of Indonesia's new opportunities : Indonesia public expenditure review 2007. Washingtong D.C.: The International Bank for Reconstruction and Development / The World Bank.
The World Bank. (2013). Indonesia Spending more or spending better : improving education financing in Indonesia. Public Expenditure Review (PER). Jakarta: World Bank Group.

The World Bank. (2013). Local governance and education performance: a survery of the quality of local education governance in 50 indonesian districts. human development. Jakarta: World Bank.

The World Bank. (n.d.). World Bank Country Indicators. Retrieved April 11, 2017, from www.worldbank.org

Wulff, J. N. (2015). Interpreting results from the multinomial logit model: demonstrated by foreign market entry. Organizational Research Methods, 18(2), 300-325.

Yulianti, N. R., Bedi, A. S., \& Bergeijk, P. V. (2015). The Functioning and effect of a cash transfer program in Indonesia. International Institute of Social Studies Research Paper.

Ziderman, A. (1997). National programmes in technical and vocational education: economic and education relationships. Journal of Vocational Education \& Training, 49(3), 351-366. 